http://dx.doi.org/10.18778/2080-8313.16.16

\title{
Aleksander Lupienko, Kamienice czynszowe Warszawy 1864-1914, War- szawa: Instytut Historii Polskiej Akademii Nauk 2015, ss. 549 + il.
}

$\bigvee_{\text {miast, co wynikało wprost z dokonujacej się wówczas rewolucji przemysło- }}^{\text {iek XIX był jak wiadomo okresem niespotykanego wczéniej rozwoju }}$ wej. W okresie tym wykształcił się również pewien charakterystyczny typ zabudowy miejskiej, jakim były kamienice czynszowe. Stanowiące oczywisty element dziedzictwa kulturowego XIX i początków XX wieku, wydają się dziś one naturalnym komponentem krajobrazu miast europejskich i kolonialnych. Tymczasem w literaturze przedmiotu interesowano się dotychczas tym fenomenem głównie pod kątem historii architektury, w niewielkim tylko stopniu opisując go jako zjawisko społeczne. Znamienne, iż analizy takie podejmowane były niemal wyłącznie w środowisku etnografów i antropologów kultury, a nie historyków. Próbą wyjścia naprzeciw tej luce jest książka Kamienice czynszowe Warszawy 1864-1914, której autorem jest adiunkt w Instytucie Historii PAN Aleksander Łupienko.

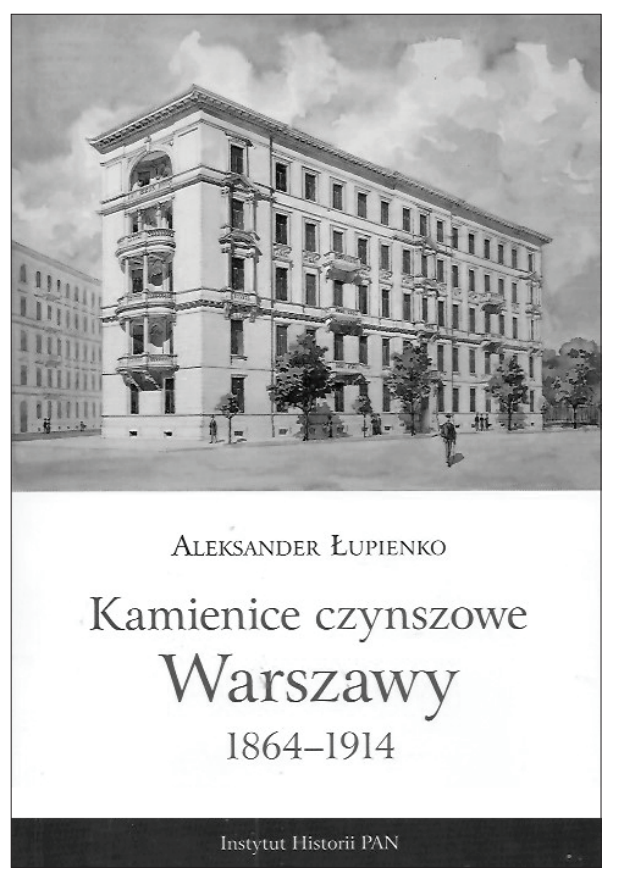

Potężna monografia składa się z dwóch części, zatytułowanych Budynek oraz Mieszkanie oraz siedmiu rozdziałów. Kluczem do zastosowania akurat takiego podziału jest teoria przestrzeni, której zróżnicowanie na publiczną i prywatną stanowiło dla Autora wskazówkę pozwalającą na opracowanie konstrukcji całej pracy. Można powiedzieć, iż A. Łupienko zaprasza czytelnika na pewną wycieczkę po świecie stołecznych kamienic, którą zaczyna od sposobu, w jaki funkcjonowały kamienice w przestrzeni publicznej (np. opisu poszczególnych dzielnic Warszawy i zróżnicowania ich zabudowy), przez podwórza, traktowane tu jako przestrzeń półpubliczna. Wejście na klatkę schodową jest przekroczeniem granicy między „publicznym”, a „prywatnym”. Zostały on bowiem zakwalifikowane do kategorii przestrzeni „półprywatnych”, by doprowadzić czytelnika do mieszkań, czyli właściwej przestrzeni prywatnej. Trzeba przyznać, iż taki podział zaproponowany przez Autora jest nader logiczny i wart wykorzystywania w pracach dotyczących przestrzeni innych miast polskich. 
Recenzowana książka oparta jest na naprawdę imponującej bazie źródłowej, na którą składają się bardzo liczny wybór wspomnień i prasy. Obszerna jest również bibliografia, w której niebagatelne miejsce zajmują prace anglo- i niemieckojęzyczne. Brakuje zdecydowanie odniesień do literatury rosyjskiej, z czego zdaje sobie sprawę sam Autor.

Czego dowiadujemy się o warszawskich kamienicach i ich lokatorach z wycieczki, po której oprowadza nas A. Łupienko? Przede wszystkim praca ta dowodzi silnego zróżnicowania i podziałów społecznych, które występowały wśród ludności Warszawy w XIX stuleciu, a które niejako materializowały się w postaci kamienicy czynszowej, ze zróżnicowanym standardem mieszkań w zależności od pozycji ekonomicznej poszczególnych grup ludności. W ten sposób mikroświat, jaki tworzyły kamienice, był jednocześnie światem silnie zhierarchizowanym, w którym fizyczna bliskość nie zawsze oznaczała wzajemne zrozumienie, a nawet znajomość życia sąsiadów z różnych warstw społecznych.

Baza źródłowa, którą dysponujemy dla tego okresu, jest niestety „skażona” przez brak świadectw tych lokatorów kamienic, którzy zamieszkiwali te „gorsze” loka, przeznaczone dla mniej zamożnych. A. Łupienko nie dysponował, w odróżnieniu np. od łódzkich etnologów, świadectw osób z kręgów robotniczych czy służby domowej, które zamieszkiwały w warszawskich kamienicach w tym okresie. Mimo to, jak ufa Autor, dokonana przez niego praca pozwala na wyciąganie pewnych wniosków ogólnych, rozjaśniających istotny fenomen społeczny przełomu XIX i XX wieku.

Praca, napisana trochę z pozycji „z lotu ptaka”, tj, oprowadzająca czytelników po poszczególnych pomieszczeniach bez bliższego poznawania poszczególnych lokatorów, stanowić może, jak sądzę, wstęp do bardziej szczegółowych badań nad kwestią miejską w Królestwie Polskim po 1864 roku. Szczególnie cenną powinna być dla tych wszystkich, którzy chcą badać dzieje poszczególnych warstw ludności miejskiej Królestwa oraz dla badaczy z Łodzi i innych ośrodków, które wciąż czekają na monografie swych kamienic i ich lokatorów.

Kamil Śmiechowski 